\title{
PERSEPSI MASYARAKAT TERHADAP RENCANA RELOKASI AKIBAT BENCANA BANJIR (STUDI KASUS KELURAHAN DENDENGAN DALAM, KECAMATAN PAAL DUA)
}

\author{
Public Perception of the Relocation Plan \\ (Case Study of Kelurahan Dendengan Dalam, Paal Dua Sub-District)
}

\author{
Frendy Oktavianus Rau \\ Benu, Olfie L. S. \\ Leonardus R. Rengkung
}

\begin{abstract}
This research aimed to describe culture, social, physical, and economy condition, to find out public perception of the relocation plan, and to identify relationship between public perception and influence factors at Lingkungan I. This research was done for three months from Agustus to October 2015 at Kelurahan Dendengan Dalam Lingkungan I, Paal Dua Sub-District, Manado City, North Sulawesi Province. This research uses descriptive qualitative with method or case study approach. Data analysed in quantitative and qualitative with statistical analysis in tabulation, percentage, and scoring and then continued with chi-squared analysis. Result showed that people condition at Lingkungan I after flood disaster didn't affect familty economy which still in passably economy but physical condition changed to weak and socio-cultural condition became good while organization condition (government socialization effort) was in passably condition because public didn't understand enough or had awareness about the relocation plan. People of Lingkungan I, Kelurahan Dendengan Dalam, doubt and didn't agree with resettlement plan of government. Most of the public attitude were attitude of passably economy condition, weaker physical and fixed condition, low and passably good organization condition, and lack of (enough) public awareness about the whole relocation plan. Factors which have connection with public perception at Lingkungan I, Kelurahan Dendengan Dalam such as organization condition (government socialication effort) and the level of knowledge about the whole relocation plan, while economy, physic, and socio-cultural condition were not affect by that.
\end{abstract}

Keywords : Public Perception, Relocation Plan, Paal Dua, Manado City

\begin{abstract}
ABSTRAK
Penelitian ini bertujuan untuk mendeskripsikan kondisi ekonomi, fisik, sosial dan budaya; mengetahui persepsi masyarakat terhadap rencana relokasi; dan mengidentifikasi hubungan antara persepsi masyarakat dengan faktor-faktor yang mempengaruhinya. Penelitian ini dilaksanakan dari bulan Agustus - Oktober 2015 dan bertempat di Lingkungan I, Kelurahan Dendengan Dalam, Kecamatan Paal Dua, Kota Manado Provinsi Sulawesi Utara. Data dianalisis secara deskriftif kualitatif dan kuantitatif dengan menggunakan analisis statistik dalam bentuk tabulasi, persentase, dan skoring, kemudian dilanjutkan dengan analisis Chi-Kuadrat. Hasil penelitian menunjukkan keadaan masyarakat di Lingkungan I, Kelurahan Dendengan Dalam pasca bencana banjir tidak mempengaruhi perekonomian keluarga yaitu tetap pada kondisi ekonomi yang cukup baik, namun kondisi fisik mengalami perubahan menjadi buruk, dan kondisi sosial budaya yang mengalami perubahan yang justru lebih membaik. Hasil penelitian juga menunjukkan bahwa kondisi organisasi (upaya sosialisasi pemerintah) berada pada kategori kurang baik, sehingga berakibat masyarakat kurang memahami/mengetahui rencana relokasi tersebut. Persepsi dari masyarakat Lingkungan I Kelurahan Dendengan Dalam terhadap rencana pemerintah untuk merelokasi pemukiman adalah ragu-ragu dan tidak setuju. Sikap masyarakat tersebut sebagian besar merupakan sikap yang diambil oleh masyarakat yang berada pada golongan kondisi ekonomi kurang baik, kondisi fisik yang memburuk dan tetap, kondisi sosial budaya yang memburuk dan membaik, dan kondisi organisasi yang kurang dan cukup baik, serta kurangnya (cukup) pengetahuan masyarakat dengan jelas secara keseluruhan rencana relokasi tersebut. Faktor - faktor yang mempunyai hubungan dengan persepsi masyarakat Lingkungan I Kelurahan Dendengan Dalam antara lain kondisi
\end{abstract}


organisasi (upaya sosialisasi pemerintah) dan tingkat pengetahuan masyarakat tentang informasi keseluruhan rencana relokasi, sedangkan yang tidak ada hubungan yaitu kondisi ekonomi, fisik, dan sosial budaya.

Kata Kunci : persepsi masyarakat, rencana relokasi, Paal Dua, Kota Manado

\section{PENDAHULUAN}

\section{Latar Belakang}

Trend bencana di Indonesia terus meningkat dari tahun ke tahun. Data menunjukkan sejak tahun 2002 bencana terjadi mengalami kenaikan, yakni tahun 2002 terjadi 190 bencana, 2005 terjadi 691 bencana dan 2010 terjadi 2.232 bencana. Bencana hidrometeorologi seperti banjir, banjir bandang, kekeringan, tanah longsor, puting beliung dan gelombang pasang merupakan jenis bencana yang dominan di Indonesia. Perubahan iklim global, degradasi lingkungan, kemiskinan, dan bertambahnya jumlah penduduk berakibat makin memperbesar ancaman risiko bencana. Data bencana tahun 2002-2011 menunjukkan bahwa sekitar $89 \%$ dari total bencana di Indonesia didominasi oleh bencana hidrometeorologi. Bencana hidrometeorologi yang sering terjadi setiap tahun yaitu bencana banjir dan diikuti tanah longsor. (Kemenkes, 2011).

Sulawesi Utara merupakan salah satu wilayah yang tak luput dari bencana banjir, terlebih khusus Kota Manado. Pada tahun 2014, peristiwa bencana banjir bandang yang terjadi pada tanggal 15 Januari telah melumpuhkan kota Manado, hampir seluruh dataran rendah terendam dan berdampak terhadap perekonomian, serta kehidupan masyarakat terganggu. Kerusakan dan kerugian yang ditimbulkan sungguh luar biasa,aset-aset publik,swasta, dan masyarakat banyak tak terselamatkan. Wilayah-wilayah yang dilalui banjir mengalami kerusakan parah, rumah dan jalan dipenuhi lumpur dan sampah. Wilayah pemukiman dan jalan yang sebelumnya bersih dan apik tampak seperti tempat pembuangan sampah sementara.

Bencana banjir bandang mengakibatkan kerugian yang cukup besar, seperti kondisi rumah dan fisik lingkungan. Laporan Pemerintah Kota Manado Sulawesi Utara kepada Badan Nasional Penanggulangan Bencana (BNPB) mengenai total kerugian akibat bencana banjir bandang yang melanda Manado dan sekitarnya pada tanggal 15 Januari 2014 diketahui berjumlah sebesar Rp 1.824.512.600.000. Data kerugian tersebut merupakan gabungan laporan kerusakan semua infrastruktur di Manado, mulai dari rumah penduduk, jalan, jembatan, drainase, tanggul sungai, talud sungai, sarana publik seperti gedung sekolah, puskesmas, rumah ibadah hingga pasar tradisional. (www.http.news liputan6.com).

Penyebab terjadinya banjir bandang di Kota Manado yaitu Daerah Aliran Sungai (DAS) tak lagi mampu menampung debit air hujan, muara sungai lebih sempit sehingga air melebur dan menghasilkan genangan yang disebut banjir. Penyempitan aliran sungai tersebut dikarenakan perilaku masyarakat yang mengalih fungsikan kawasan bantaran sungai menjadi pemukiman penduduk. Mengingat kondisi tersebut, pemerintah Sulawesi Utara dalam hal ini pemerintah Kota Manado tengah berupaya untuk menanggulanginya, salah satu upaya pemerintah Kota Manado dalam menanggulangi masalah banjir yang terjadi di daerah aliran sungai yaitu dengan cara merelokasikan penduduk sekitar DAS. Ketentuan wilayah yang akan direlokasi yaitu yang termasuk dalam jangkauan jarak 15 - 20 meter dari sungai. Kelurahan Dendengan Dalam Kecamatan Tikala Kota Manado, terlebih khusus Lingkungan I merupakan salah satu yang termasuk dalam kriteria wilayah yang akan direlokasi.

\section{Permasalahan}

1. Bagaimana kondisi ekonomi, fisik, sosialbudaya, dan kondisi organisasi pada masyarakat Lingkungan I, serta tingkat pengetahuan masyarakat tentang rencana relokasi ? 
2. Bagaimana persepsi masyarakat terhadap rencana relokasi pada masyarakat Lingkungan I ?

3. Faktor-faktor apa saja yang mempunyai hubungan dengan persepsi masyarakat terhadap rencana relokasi pada masyarakat Lingkungan I?

\section{Tujuan Penelitian}

1. Mendeskripsikan kondisi ekonomi, fisik, sosial-budaya, dan kondisi organisasi pada masyarakat Lingkungan I, serta tingkat pengetahuan masyarakat tentang rencana relokasi.

2. Mengetahui persepsi masyarakat terhadap rencana relokasi pada masyarakat Lingkungan I.

3. Mengidentifikasi hubungan antara persepsi masyarakat dengan faktor-faktor yang mempengaruhinya.

\section{METODOLOGI PENELITIAN}

\section{Waktu dan Tempat Penelitian}

Penelitian ini dilaksanakan selama 3 (tiga) bulan yaitu terhitung mulai dari bulan Agustus sampai dengan bulan Oktober 2015. Lokasi penelitian di Kelurahan Dendengan Dalam Lingkungan I, Kecamatan Paal Dua Kota Manado Provinsi Sulawesi Utara.

\section{Jenis Penelitian}

Jenis Penelitian ini menggunakan metode atau pendekatan studi kasus (Case Study), yang dimaksudkan untuk mempelajari secara intensif tentang latar belakang masalah keadaan dan posisi suatu peristiwa yang sedang berlangsung saat ini, serta interaksi lingkungan unit sosial tertentu yang bersifat apa adanya (given). Subjek penelitian dapat berupa individu, kelompok, institusi atau masyarakat (Nawawi, 2003).

\section{Jenis dan Sumber Data}

Data yang digunakan dalam penelitian ini adalah data primer dan data sekunder. Data primer diperoleh melalui hasil wawancara langsung kepada responden dan data sekunder diperoleh melalui studi literatur dan studi pustaka yang diperoleh dari instansi-instansi terkait.
Teknik Pengambilan Sampel

Pengambilan sampel tempat dan responden dilakukan secara purposive sampling atau secara sengaja. Penentuan tempat sengaja dipilih telah diuraikan sebelumnya yaitu berdasarkan rencana pemerintah kota yang menetapkan bahwa Kelurahan Dendengan Dalam Lingkungan I termasuk wilayah yang terkena relokasi, karena terletak di pinggiran DAS Tondano Sampel responden masyarakat tersebut diwakili kepala keluarga (KK), dengan jumlah populasi KK di Kelurahan Dendengan Dalam Lingkungan I yang khusus berdomisili sejauh $10-15$ meter dari pinggirian DAS Tondano yaitu sebanyak $30 \mathrm{KK}$.

\section{Hipotesis Penelitian}

Hipotesis nol $\left(\mathrm{H}_{0}\right)$, yaitu :

a. Diduga tidak ada hubungan antara kondisi ekonomi dengan persepsi masyarakat tentang rencana relokasi.

b. Diduga tidak ada hubungan antara kondisi sosial budaya dengan persepsi masyarakat tentang rencana relokasi

c. Diduga tidak ada hubungan antara kondisi fisik dengan persepsi masyarakat tentang rencana relokasi

d. Diduga tidak ada hubungan antara kondisi organisasi (upaya sosialisasi pemerintah) dengan persepsi masyarakat tentang rencana relokasi.

e. Diduga tidak ada hubungan antara pengetahuan masyakat tentang rencana relokasi dengan persepsi masyarakat.

f. Diduga tidak ada hubungan antara kondisi ekonomi masyarakat dengan persepsi masyarakat tentang rencana relokasi.

Hipotesis alternatif $\left(\mathrm{H}_{1}\right)$, yaitu :

a. Diduga ada hubungan antara kondisi sosial budaya dengan persepsi masyarakat tentang rencana relokasi.

b. Diduga ada hubungan antara kondisi fisik dengan persepsi masyarakat tentang rencana relokasi

c. Diduga ada hubungan antara kondisi organisasi (upaya sosialisasi pemerintah) dengan persepsi masyarakat tentang rencana relokasi.

d. Diduga ada hubungan antara pengetahuan masyakat tentang rencana relokasi dengan persepsi masyarakat. 
e. Diduga ada hubungan antara kondisi ekonomi masyarakat dengan persepsi masyarakat tentang rencana relokasi.

\section{Konsep Pengukuran Variabel}

Variabel - variabel yang diukur dalam penelitian ini yaitu meliputi:

1. Karakteristik Responden, antara lain :

a) Umur, yakni usia responden pada saat wawancara dilakukan. Dibedakan menjadi dua kategori yaitu: 1) Produktif, kisaran umur $\leq 55$ tahun; dan 2) Non Produktif, kisaran umur $>55$ tahun.

b) Tingkat pendidikan, yakni jenjang sekolah formal yang pernah diikuti. Dibedakan menjadi tiga kategori, yaitu 1) Rendah, jika lulus SD dan SMP/SLTP; 2) Sedang, jika lulus SMU/SLTA/Kejuruan; dan 3) Tinggi, jika lulus Perguruan Tinggi/Akademi/ Diploma.

c) Jumlah tanggungan, yakni banyaknya jumlah anggota keluarga yang pasti menetap dan menjadi tanggungan responden. Dibedakan menjadi tiga kategori, yaitu : 1) Sedikit, jika berjumlah lebih rendah dari tiga orang;

2) Cukup, jika berjumlah 3-4 orang; dan

3) Banyak, jika berjumlah lebih dari empat orang.

d) Pekerjaan, yakni pekerjaan responden yang meliputi status pekerjaan dan jenis pekerjaan. Status pekerjaan dibedakan menjadi tiga kategori yang terdiri atas tetap, tidak tetap, dan tidak bekerja.

e) Tempat tinggal, yakni rumah yang ditempati sekarang meliputi :

1. Lama tinggal, yakni lamanya menetap yang terdiri atas : $<10$ tahun, dan $\geq 10$ tahun.

2. Status kepemilikan, yakni rumah yang ditempati merupakan milik pribadi (milik sendiri / milik keluarga) dan sewa / kontrakan.

3. Jenis rumah, yakni terdiri atas rumah permanen, semi permanen, dan tidak permanen.

f) Pendapatan, yakni penghasilan yang diperoleh oleh kepala keluarga dalam satu bulan (Rp/bulan).
2. Variabel bebas (independent), meliputi :

a. Kondisi Ekonomi, yakni kondisi perekonomian dari keluarga responden sebelum dan pasca bencana banjir. Dibedakan menjadi tiga kategori, yaitu: 1) Kurang baik; 2) Cukup baik; dan 3) Baik.

b. Kondisi fisik/lingkungan, yakni kondisi sarana, prasarana atau infrastruktur di wilayah penelitian sebelum dan pasca bencana banjir. Dibedakan menjadi tiga kategori yaitu: 1) Memburuk; 2) Tidak ada perubahan; dan 3) Membaik.

c. Kondisi sosial budaya, yakni kondisi sosial budaya di wilayah penelitian sebelum dan pasca bencana banjir. Dibedakan menjadi tiga kategori yaitu : 1) Memburuk; 2) Tidak ada perubahan; dan 3) Membaik.

d. Kondisi Organisasi, yakni kondisi hubungan pemerintah dan masyarakat menyangkut rencana relokasi di wilayah penelitian. Kondisi ini dilihat dari upaya yang dilakukan pemerintah untuk mensosialisasikan program rencana relokasi. Dibedakan menjadi tiga kategori yaitu : 1) Kurang baik; 2) Cukup baik; dan 3) Baik.

e. Pengetahuan/pemahaman masyarakat tentang rencana relokasi, yakni seberapa besar tingkat pengetahuan/pemahaman masyarakat lingkungan I terhadap rencana relokasi. Dibedakan menjadi tiga kategori, yaitu: 1) Tidak Mengetahui; 2) Cukup mengetahui; dan 3) Tidak mengetahui.

3. Variabel terikat (dependent), yakni persepsi masyarakat Lingkungan I terhadap rencana relokasi, yaitu penilaian/pendapat/sikap masyarakat terhadap rencana pemerintah untuk merelokasi pemukiman mereka. Pengukuran persepsi masyarakat ini berdasarkan pertanyaan kepada responden dengan tiga jawaban, yaitu : 1) Tidak setuju; 2) Ragu-ragu; dan 3) Setuju.

\section{Metode Analisis Data}

Data dianalisis secara deskriftif kuantitatif yang dimaksudkan untuk mengolah dan mengorganisasikan data secara statistik dalam bentuk tabulasi, persentase, dan skoring, serta 
analisis uji Chi-Square, sehingga menemukan hasil yang dapat dibaca dan diinterpretasikan. Pengukuran variabel bebas kondisi ekonomi.

\section{HASIL DAN PEMBAHASAN}

\section{Kondisi Ekonomi Keluarga}

Pembahasan kondisi ekonomi pada penelitian ini dimaksudkan untuk mendeskripsikan kondisi ekonomi responden dalam beberapa kategori berdasarkan indikator karakteristik responden yang dinilai berkaitan, yaitu antara lain: pendapatan, dan status pekerjaan. Hasil wawancara mendapati bencana banjir beberapa waktu lalu tidak mempengaruhi kedua indikator kondisi ekonomi tersebut. Ini berarti kondisi ekonomi sebelum dan sesudah bencana banjir tidak berubah, sehingga penentuan kategori kondisi ekonomi terdiri atas: baik, cukup, dan kurang. Pengukuran indikator pendapatan, dan status pekerjaan,rumah dilak kan dengan metode deskriptif berupa pembobotan, selanjutnya dibuat scoring dengan menggunakan skala tingkat (rating scale) menurut Skala Likert. Data yang diperoleh kemudian didistribusikan dalam kategori berbeda-beda berdasarkan kelas-kelas interval tertentu, kemudian ditentukanlah kategori untuk keseluruhan responden melalui tabulasi dan persentase.Pada indikator pendapatan, pemberian skor meliputi : 1) kurang dari Rp 3 juta diberi skor 1 ; 2) antara Rp 3 juta s/d Rp 4 juta diberi skor 2; dan 3) diatas Rp 4 juta diberi skor 3. Pada status pekerjaan, pemberian skor meliputi : 1) tidak bekerja diberi skor 1;2) tidak tetap diberi skor 2; dan 3) tetap diberi skor 3.

Berdasarkan uraian tersebut, dengan demikian penentuan kategori kondisi ekonomi keluarga, yaitu sebagai berikut :

$$
\begin{array}{ll}
\text { 1) }<3 & =\text { Kurang baik } \\
\text { 2) } 3-4 & =\text { Cukup baik } \\
\text { 3) } 5-6 & =\text { Baik }
\end{array}
$$

Hasil analisis penentuan kategori kondisi ekonomi pada masyarakat Lingkungan I Kelurahan Dendengan Dalam, dapat dilihat pada Tabel 1.

\section{Tabel 1. Penilaian Responden Menurut Kondisi Ekonomi}

\begin{tabular}{lcc}
\hline \multirow{2}{*}{ Kondisi } & \multicolumn{2}{c}{ Responden } \\
\cline { 2 - 3 } Ekonomi & $\begin{array}{c}\text { Jumlah } \\
(\text { KK) }\end{array}$ & Persentase (\%) \\
\hline Kurang & 2 & 6,66 \\
baik & 24 & 80,00 \\
Cukup & 4 & 13,34 \\
baik & & \\
Baik & & \\
\hline Jumlah & 30 & 100,00 \\
\hline
\end{tabular}

Sumber: Diolah dari data primer, 2015

Pada Tabel 1, diperoleh bahwa Persentase responden dengan kondisi ekonomi kategori kurang baik yaitu sebesar 6,67 persen, dan kategori cukup baik sebesar 80 persen, sedangkan kategori kurang baik sebesar 13,33 persen. Mencermati data tersebut, dapat disimpulkan kondisi ekonomi masyarakat Lingkungan I berada pada kategori yang cukup baik.

Berdasarkan penjelasan diatas, diketahui perekonomian masyarakat Lingkungan I pasca bencana banjir tidak berubah yaitu berada dalam kondisi yang cukup baik. Kondisi tersebut sangat beralasan, karena berdasarkan hasil penelitian mendapati sebagian besar masyarakat menghasilkan pendapatan yang berkisaran Rp 3 juta s/d Rp 4 juta, yakni ratarata berpendapatan $\mathrm{Rp} 2.908 .333$, yang dihasilkan dari pekerjaan yang tidak tetap sebagai wiraswasta dan buruh.

\section{Kondisi Situasi/Lingkungan}

\section{Kondisi Fisik}

Kondisi fisik yang dimaksudkan yaitu meliputi sarana dan prasarana, infrastruktur yang tersedia di lingkungan, seperti kondisi sekolah, tempat ibadah, jalan, drainase, dan ketersediaan air bersih. Penilaian masyarakat terhadap kondisi fisik dilakukan berdasarkan kondisi sebelum dan sesudah bencana banjir, yang dibedakan menjadi 3 (tiga) kategori, yaitu: memburuk, tidak ada perubahan, dan membaik. Frekuensi penilaian responden menurut kondisi fisik pada masyarakat Lingkungan I, dapat dilihat pada Tabel 2. 
Tabel 2. Penilaian Responden Menurut Kondisi Fisik

\begin{tabular}{lcc}
\hline \multirow{2}{*}{ Kondisi Fisik } & \multicolumn{2}{c}{ Responden } \\
\cline { 2 - 3 } & $\begin{array}{c}\text { Jumlah } \\
(\text { KK })\end{array}$ & $\begin{array}{c}\text { Persentase } \\
(\%)\end{array}$ \\
\hline Memburuk & 16 & 53,33 \\
Tidak ada & 14 & 46,67 \\
perubahan & 0 & 0 \\
Membaik & &
\end{tabular}

\begin{tabular}{ccc}
\hline Jumlah & 30 & 100,00 \\
\hline Sumber : Diolah dari data primer, & 2015
\end{tabular}

Pada Tabel 2 diperoleh persentase penilaian responden terbesar ialah responden yang menilai kondisi fisik pasca bencana banjir memburuk yaitu sebesar 53,33 persen, diikuti responden yang menilai kondisi fisik tidak mengalami perubahan yaitu sebesar 46,67 persen. Tidak ada satupun responden yang menilai kondisi fisik pasca bencana banjir di Lingkungan I membaik. Uraian tersebut menunjukkan bahwa sebagian besar masyarakat menilai kondisi fisik di Lingkungan I pasca bencana banjir memburuk, dengan kata lain sarana dan prasarananya memburuk.

Penilaian masyarakat terhadap kondisi fisik dilihat dari kondisi sarana dan prasarana di Lingkungan I pasca bencana banjir. Hasil analisis yang mendapati sebagian besar masyarakat menilai kondisi fisik pasca bencana banjir memburuk, didasarkan pada pemahaman masyarakat yang menilai kondisi fisik tersebut berdasarkan fungsi dan tampilannya. Realitas memperlihatkan bencana banjir mengakibatkan kondisi bangunan menjadi kotor, jalan yang terkikis, drainase yang terhambat karena kotoran sampah lumpur, dan kondisi kualitas air bersih yang dirasa berkurang. Kondisi tersebut menjadi acuan masyarakat menilai kondisi fisik pasca bencana banjir memburuk.

Bertolak belakang dengan uraian diatas, masyarakat yang menilai tidak ada perubahan lebih menekankan pada fungsi sarana prasarana yang tidak berubah pasca bencana banjir. Masyarakat menilai pasca bencana banjir, sarana prasarana yang ada masih tetap berfungsi atau masih bisa digunakan. Dampak banjir dirasa merugikan hanya pada saat banjir dan sesaat setelah surut, karena bangunan dipenuhi kotoran lumpur dan sampah sehingga belum bisa digunakan, contohnya yaitu bangunan mushola yang masih tetap digunakan sampai sekarang, dan kondisi jalan yang masih layak dilewati kendaraan.

\section{Kondisi Sosial Budaya}

Kondisi sosial budaya merupakan kondisi lingkungan yang menggambarkan perilaku masyarakat dan hubungan antar masyarakat. Kondisi sosial budaya pada penelitian ini meliputi segala kegiatan sosial atau kemasyarakatan yang rutin maupun tidak rutin dilaksanakan, kondisi kesehatan, kebersihan, keamanan, dan kenyamanan. Penilaian kondisi sosial budaya ini didasarkan pada kondisi sebelum dan sesudah bencana banjir, agar diketahui perubahan sosial budaya yang terjadi. Selanjutnya penilaian tersebut dibedakan menjadi tiga kategori, yaitu: memburuk, tidak ada perubahan, dan membaik.

Frekuensi penilaian responden menurut kondisi sosial budaya pada masyarakat Lingkungan I, dapat dilihat pada Tabel 3.

\section{Tabel 3. Penilaian Responden Menurut} Kondisi Sosial Budaya

\begin{tabular}{lcc}
\hline \multirow{2}{*}{$\begin{array}{l}\text { Kondisi Sosial } \\
\text { Budaya }\end{array}$} & \multicolumn{2}{c}{ Responden } \\
\cline { 2 - 3 } & $\begin{array}{c}\text { Jumlah } \\
(\mathrm{KK})\end{array}$ & $\begin{array}{c}\text { Persentase } \\
(\%)\end{array}$ \\
\hline Memburuk & 5 & 16,67 \\
Tidak ada & 9 & 30,00 \\
perubahan & 16 & 53,33 \\
Membaik & & \\
\hline Jumlah & 30 & 100,00 \\
\hline
\end{tabular}

Sumber : Diolah dari data primer, 2015

Tabel 3 diperoleh bahwa responden yang menilai kondisi sosial budaya di Lingkungan I memburuk yaitu sebesar 16,67 persen, tidak mengalami perubahan sebesar 30,00 persen, sedangkan yang menilai membaik yaitu sebesar 53,33 persen. Berdasarkan data tersebut dapat disimpulkan bahwa kondisi sosial budaya di Lingkungan I semakin membaik. Hal ini menunjukkan bencana banjir yang terjadi beberapa waktu lalu, tidak mengurangi hubungan sosial yang terjalin, justru lebih meningkatkan kegiatan-kegiatan sosial terutama 
kegiatan yang berhubungan dengan kemanusiaan (penggalangan donor darah), kesehatan (penyuluhan kesehatan, Posyandu), kebersihan (kerja bakti setiap bulan 2 kali), keamanan (jaga malam bergilir), kegiatan gotong-royong, PKK, dan Pertemuan rukunrukun.

\section{Kondisi Organisasi (Upaya Sosialisasi Pemerintah)}

Kondisi organisasi ditujukan mengenai kondisi hubungan pemerintah dengan masyarakat. Bentuk hubungan yang dimaksudkan yaitu berkenaan dengan bagaimana pemerintah mewujudkan rencana relokasi pemukiman, melalui upaya dengan kegiatan-kegiatan yang memperkenalkan dan menginformasikan rencana relokasi kepada masyarakat khususnya yang berdomisili di wilayah yang menjadi sasaran. Kegiatan yang dimaksudkan tersebut dilakukan dalam bentuk komunikasi dua arah seperti sosialisasi atau pertemuan langsung dengan masyarakat, dan komunikasi satu arah seperti penyebaran informasi melalui media. Berikut penilaian responden terhadap upaya sosialisasi pemerintah pada masyarakat Lingkungan I, yang terangkum pada Tabel 4.

Tabel 4. Penilaian Responden Terhadap Upaya Sosialisasi Pemerintah

\begin{tabular}{lcc}
\hline \multirow{2}{*}{$\begin{array}{c}\text { Upaya } \\
\text { Sosialisasi }\end{array}$} & \multicolumn{2}{c}{ Responden } \\
\cline { 2 - 3 } & Jumlah & Persentase \\
& $($ KK $)$ & $(\%)$ \\
\hline Kurang & 19 & 63,33 \\
baik & 11 & 36,67 \\
Cukup & 0 & 0 \\
baik & & \\
Baik & &
\end{tabular}

\begin{tabular}{lcc}
\hline Jumlah & 30 & 100,00 \\
\hline Sumber : Diolah dari data primer, 2015
\end{tabular}

Pada Tabel 4, diperoleh persentase terbesar penilaian responden terhadap upaya sosialisasi pemerintah yaitu sebesar 63,33 persen responden menjawab kurang baik. Selebihnya yaitu sebesar 36,67 persen responden menilai upaya pemerintah untuk mensosialisasikan rencana relokasi tersebut cukup baik. Tidak ada satupun responden yang menilai upaya sosialisasi pemerintah termasuk kategori baik.
Uraian diatas dapat disimpulkan bahwa sebagian besar masyarakat Lingkungan I menilai kondisi organisasi (upaya sosialisasi pemerintah) kurang baik. Ini menandakan upaya pemerintah sangat kurang dalam mensosialisasikan rencana relokasi di wilayah lingkungan I. Hasil penelitian mendapati bahwa cukup banyak masyarakat yang mengakui pernah mendengar atau mengetahui rencana pemerintah tersebut, namun sumber informasi diperoleh melalui penyampaian secara mouth to mouth yang kebenarannya diragukan, dan adanya perbedaan informasi tentang rencana relokasi yang diterima oleh masyarakat.

\section{Pengetahuan Masyarakat Tentang Rencana Relokasi}

Pentingnya sosialisasi yang diupayakan oleh pemerintah langsung kepada masyarakat yang berdomisili di wilayah sasaran rencana relokasi, dimaksudkan agar tidak ada kesalahpahaman dari masyarakat akibat ketidaktahuan masyarakat tentang apa, maksud dan bagaimana rencana relokasi. Persepsi masyarakat yang terbentuk tentunya akan lebih baik jika didasari oleh karena masyarakat telah mengetahui dan mengerti akan rencana relokasi tersebut. Dengan demikian, sangat diharapkan masyarakat mampu memberikan alasan-alasan/saran/masukan atas tindakan apapun yang diambil oleh masyarakat terhadap rencana pemerintah tersebut, sebagai bahan pertimbangan pemerintah untuk mewujudkan rencana relokasi yang sesuai dengan keinginan masyarakat. Penilain responden menurut pengetahuan masyarakat tentang apa, maksud dan bagaimana rencana relokasi, dapat dilihat pada Tabel 5.

\section{Tabel 5. Penilaian Responden Menurut} Pengetahuan Masyarakat

\begin{tabular}{lcc}
\hline \multirow{2}{*}{$\begin{array}{l}\text { Pengetahuan } \\
\text { Masyarakat }\end{array}$} & \multicolumn{2}{c}{ Responden } \\
\cline { 2 - 3 } & $\begin{array}{c}\text { Jumlah } \\
(\mathrm{KK})\end{array}$ & $\begin{array}{c}\text { Persentase } \\
(\%)\end{array}$ \\
\hline Tidak & 6 & 20,00 \\
mengetahui & 21 & 70,00 \\
Cukup & 3 & 10,00 \\
mengetahui & & \\
Mengetahui & &
\end{tabular}

Jumlah $\quad 30 \quad 100,00$

Sumber : Diolah dari data primer, 2015 
Pada Tabel 5, diperoleh persentase terbesar penilaian responden menurut pengetahuan masyarakat yaitu sebesar 70 persen responden menjawab cukup mengetahui, dalam arti informasi kurang lengkap. Selanjutnya yaitu sebesar 20 persen responden menjawab tidak mengetahui, dan sebesar 10 persen responden mengetahui tentang rencana relokasi. Hal ini menunjukkan sebagian besar masyarakat di Lingkungan I mengetahui tentang rencana relokasi, namun belum mengerti secara keseluruhan karena informasi yang tidak lengkap sehingga ada berbagai perbedaan pengertian atau pemahaman.

\section{Persepsi Masyarakat Terhadap Rencana Relokasi}

1. Frekuensi Persepsi Masyarakat terhadap Rencana Relokasi

Salah satu upaya pemerintah Kota Manado dalam penanggulangan bencana banjir yaitu melalui rencana relokasi terhadap masyarakat yang berdomisi di pinggiran sungai. Wilayah Kelurahan Dendengan Dalam termasuk didalamnya Lingkungan I merupakan salah satu wilayah yang menjadi sasaran rencana relokasi. Atas maksud pemerintah tersebut, maka sangat menarik untuk mengetahui persepsi masyarakat terhadap rencana relokasi. Persepsi masyarakat terhadap rencana relokasi di Kelurahan Dendengan Dalam Lingkungan I, dapat dilihat pada Tabel 6.

Tabel 6. Persepsi Masyarakat Terhadap Rencana Relokasi

\begin{tabular}{lcc}
\hline \multirow{2}{*}{$\begin{array}{l}\text { Persepsi } \\
\text { Masyarakat }\end{array}$} & \multicolumn{2}{c}{ Responden } \\
\cline { 2 - 3 } & Jumlah (KK) & $\begin{array}{c}\text { Persentase } \\
(\%)\end{array}$ \\
\hline Tidak setuju & 13 & 43,33 \\
Ragu-ragu & 13 & 43.33 \\
Setuju & 4 & 13,34 \\
\hline Jumlah & 30 & 100,00
\end{tabular}

\section{Sumber : Diolah dari data primer, 2015}

Berdasarkan Tabel 6, diperoleh bahwa persentase responden yang menyatakan tidak setuju dan ragu-ragu dengan rencana relokasi sebagai langkah tepat untuk penanggulangan banjir di Lingkungan I berbagi sama besar yaitu masing-masing 43,33 persen. Selebihnya sebesar 13,33 persen setuju dengan rencana relokasi yang dilakukan pemerintah. Uraian tersebut dapat disimpulkan bahwa sebagian besar masyarakat Lingkungan I merasa raguragu dan tidak setuju dengan rencana relokasi.

\section{Persepsi Masyarakat Menurut Faktor - Faktor yang Mempengaruhinya}

\section{a. Kondisi Ekonomi}

Persepsi masyarakat terhadap rencana relokasi dipengaruhi oleh beberapa faktor, salah satunya yaitu kondisi ekonomi masyarakat. Hasil penelitian mendapati bahwa sebagian besar masyarakat Lingkungan I berada pada kondisi ekonomi yang cukup baik. Berikut persepsi masyarakat terhadap rencana relokasi menurut kondisi ekonomi yang terangkum pada Tabel 6.

Berdasarkan Tabel 7, diketahui bahwa persepsi masyarakat pada kondisi ekonomi kurang baik, tidak satupun responden yang menyatakan setuju dengan rencana relokasi. Sebagian besar masyarakat pada kategori ini yaitu sebesar 50 persen responden merasa tidak setuju dan ragu-ragu dengan rencana relokasi. Persepsi masyarakat pada kondisi ekonomi cukup baik terdistribusi pada sikap tidak setuju yaitu sebesar 45,83 persen, sikap ragu-ragu sebesar 41,67 persen, dan setuju sebesar 12,50 persen. Persepsi masyarakat pada kondisi ekonomi yang baik, diperoleh responden yang tidak setuju dan setuju berbagi sama besar yaitu 25 persen, dan selebihnya sebesar 50 persen menyatakan ragu-ragu dengan rencana relokasi.

Uraian tersebut dapat disimpulkan bahwa berdasarkan kondisi ekonomi kurang baik sebagian besar menyatakan tidak setuju dan ragu-ragu dengan rencana relokasi. Pada kondisi ekonomi cukup baik sebagian besar menyatakan tidak setuju, sedangkan pada kategori ekonomi baik, sebagian besar menyatakan merasa ragu-ragu dengan rencana relokasi.

\section{b. Kondisi Fisik}

Kondisi fisik pasca bencana banjir di lingkungan I dan sekitarnya, serta kondisi fisik yang telah ada atau yang akan dibangun di lokasi tujuan dari 
rencana pemerintah, turut mempengaruhi persepsi masyarakat. Berkenaan dengan hal tersebut, penelitian ini lebih mengacu pada kondisi fisik di lokasi terkena rencana relokasi, dan diperoleh hasil penilaian yang terdistribusi pada dua kondisi fisik yaitu tidak ada perubahan dan memburuk. Diantara kedua kondisi tersebut, sebagian besar masyarakat menilai kondisi fisik pasca bencana banjir mengalami perubahan yang cenderung memburuk. Persepsi masyarakat terhadap rencana relokasi menurut kondisi fisik pasca bencana banjir di Lingkungan I dan sekitarnya, dapat dilihat pada Tabel 8.

Berdasarkan Tabel 8, diperoleh bahwa persepsi masyarakat pada kondisi fisik memburuk menyatakan tidak setuju yaitu sebesar 43,75 persen, ragu-ragu sebesar 37,50 persen, dan setuju sebesar 18,75 persen. Pada kondisi fisik tidak ada perubahan yang berpendapat tidak setuju sebesar 42,86 persen ragu-ragu sebesar 50 persen, dan setuju 7,14 persen. Dengan demikian dapat disimpulkan persepsi masyarakat berdasarkan kondisi fisik memburuk sebagian besar menyatakan tidak setuju dengan rencana relokasi, sedangkan pada kondisi fisik tidak berubah sebagian besar menyatakan ragu-ragu. c. Kondisi Sosial-Budaya

Kondisi sosial budaya yaitu kondisi lingkungan yang mendeskripsikan bagaimana kegiatan-kegiatan sosial, kondisi kesehatan, pendidikan, kenyamanan, dan keamanan yang tercipta pasca bencana banjir. Hasil penelitian mendapati bahwa kondisi sosial budaya di Lingkungan I dinilai mengalami peningkatan pasca bencana banjir. Persepsi masyarakat terhadap rencana relokasi menurut kondisi sosial budaya, dapat dilihat pada Tabel 9.

Berdasarkan Tabel 9, diperoleh bahwa persepsi masyarakat pada kondisi sosial budaya memburuk yang menyatakan tidak setuju yaitu sebesar 60 persen, ragu-ragu sebesar 20 persen, dan setuju sebesar 20 persen. Pada kondisi sosial budaya tidak berubah, persepsi masyarakat yang tidak setuju dan ragu-ragu menghasilkan persentase yang sama yaitu sebesar 44,44 persen, dan selebihnya sebesar 11,12 persen menyatakan setuju. Pada kondisi sosial budaya membaik, persepsi masyarakat yang menyatakan tidak setuju yaitu sebesar 60 persen, sedangkan masyarakat yang menyatakan ragu-ragu menghasilkan persentase yang sama besar dengan sikap setuju yaitu sebesar 20 persen.

Tabel 7. Persepsi Masyarakat Menurut Kondisi Ekonomi

\begin{tabular}{|c|c|c|c|c|c|c|c|c|}
\hline \multirow{3}{*}{ Kondisi Ekonomi } & \multicolumn{6}{|c|}{ Persepsi Masyarakat } & \multirow{2}{*}{\multicolumn{2}{|c|}{ Total }} \\
\hline & \multicolumn{2}{|c|}{ Tidak setuju } & \multicolumn{2}{|c|}{ Ragu-ragu } & \multicolumn{2}{|c|}{ Setuju } & & \\
\hline & Jml & $\%$ & $\mathrm{Jml}$ & $\%$ & $\mathrm{Jml}$ & $\%$ & $\mathrm{Jml}$ & $\%$ \\
\hline Kurang baik & 1 & 50,00 & 1 & 50,00 & 0 & 0 & 2 & 6,66 \\
\hline Cukup baik & 11 & 45,83 & 10 & 41,67 & 3 & 12,50 & 24 & 80,00 \\
\hline Baik & 1 & 25,00 & 2 & 50,00 & 1 & 25,00 & 4 & 13,34 \\
\hline Total & 13 & 43,33 & 13 & 43,33 & 4 & 13,34 & 30 & 100,00 \\
\hline
\end{tabular}

Sumber : Diolah dari data primer, 2015

Tabel 8. Persepsi Masyarakat Menurut Kondisi Fisik

\begin{tabular}{|c|c|c|c|c|c|c|c|c|}
\hline \multirow{3}{*}{ Kondisi Fisik } & \multicolumn{6}{|c|}{ Persepsi Masyarakat } & \multirow{2}{*}{\multicolumn{2}{|c|}{ Total }} \\
\hline & \multicolumn{2}{|c|}{ Tidak setuju } & \multicolumn{2}{|c|}{ Ragu-ragu } & \multicolumn{2}{|c|}{ Setuju } & & \\
\hline & $\mathrm{Jml}$ & $\%$ & $\mathrm{Jml}$ & $\%$ & $\mathrm{Jml}$ & $\%$ & $\mathrm{Jml}$ & $\%$ \\
\hline Memburuk & 7 & 43,75 & 6 & 37,50 & 3 & 18,75 & 16 & 53,33 \\
\hline $\begin{array}{l}\text { Tidak ada } \\
\text { perubahan }\end{array}$ & 6 & 42,86 & 7 & 50,00 & 1 & 7,14 & 14 & 46,67 \\
\hline Membaik & 0 & 0 & 0 & 0 & 0 & 0 & 0 & 0 \\
\hline Total & 13 & 43,33 & 13 & 43,33 & 4 & 13,34 & 30 & 100,00 \\
\hline
\end{tabular}

Sumber : Diolah dari data primer, 2015 
Berdasarkan uraian tersebut, dapat disimpulkan persepsi masyarakat berdasarkan kondisi sosial budaya yang memburuk, se-bagian besar menyatakan tidak setuju dengan rencana relikasi. Pada kondisi yang tidak akan berubah, sebagian besar masyarakat menyatakan tidak setuju dan ragu-ragu, sedangkan masyarakat yang menilai kondisi sosial budaya membaik, menyatakan raguragu dengan rencana relokasi.

d. Kondisi Organisasi (Upaya Sosialisasi Pemerintah)

Faktor lain yang tidak kalah penting dalam rangka pembentukan persepsi masyarakat lingkungan I terhadap rencana relokasi yaitu kondisi organisasi yang menitikberatkan upaya pemerintah untuk sosialisasi tentang rencana pemerintah tersebut untuk memberi pengertian/ pemahaman kepada masyarakat. Hasil penelitian mendapati bahwa masyarakat yang berpersepsi tidak setuju, sebagian besar mengaku jarang bahkan tidak pernah ada upaya pemerintah untuk mensosialisasikan rencana relokasi tersebut. Berikut persepsi masyarakat terhadap rencana relokasi menurut kondisi organisasi, dapat dilihat pada Tabel 10.

Pada Tabel 10, diperoleh bahwa kategori pada kondisi organisasi menghasilkan dua kategori yaitu kurang baik dan cukup baik. Persepsi masyarakat pada penilaian kondisi organisasi kurang baik yang menyatakan tidak setuju dengan rencana relokasi yaitu sebesar 63,16 persen, ragu-ragu sebesar 31,58 persen, dan setuju sebesar 5,26 persen. Pada penilaian kondisi organisasi cukup baik, masyarakat yang menyatakan tidak setuju yaitu sebesar 9,09 persen, ragu-ragu sebesar 63,64 persen, dan setuju sebesar 27,27 persen. Berdasarkan uraian tersebut, dapat disimpulkan persepsi masyarakat berdasarkan kondisi organisasi kurang baik, sebagian besar masyarakat menyatakan tidak setuju. Sedangkan pada kondisi organisasi cukup baik, sebagian besar merasa ragu dengan rencana relokasi.

Tabel 9. Persepsi Masyarakat Menurut Kondisi Sosial Budaya

\begin{tabular}{ccccccccc}
\hline Kondisi & \multicolumn{4}{c}{ Persepsi Masyarakat } & \multicolumn{2}{c}{ Total } \\
\cline { 2 - 7 } $\begin{array}{c}\text { Sosial } \\
\text { Budaya }\end{array}$ & \multicolumn{2}{c}{ Tidak setuju } & \multicolumn{2}{c}{ Ragu-ragu } & \multicolumn{2}{c}{ Setuju } & \multicolumn{2}{c}{ Jml } \\
\hline Memburuk & 3 & 60,00 & 1 & 20,00 & 1 & 20,00 & 5 & 16,67 \\
$\begin{array}{c}\text { Tidak ada } \\
\text { perubahan }\end{array}$ & 4 & 44,44 & 4 & 44,44 & 1 & 11,12 & 9 & 30,00 \\
Membaik & 6 & 37,50 & 8 & 50,00 & 2 & 12,50 & 16 & 53,33 \\
\hline Total & 13 & 43,33 & 13 & 43,33 & 4 & 13,34 & 30 & 100,00 \\
\hline
\end{tabular}

Sumber : Diolah dari data primer, 2015

Tabel 10. Persepsi Masyarakat Menurut Kondisi Organisasi

\begin{tabular}{|c|c|c|c|c|c|c|c|c|}
\hline \multirow{3}{*}{$\begin{array}{l}\text { Kondisi } \\
\text { Organisasi }\end{array}$} & \multicolumn{6}{|c|}{ Persepsi Masyarakat } & \multirow{2}{*}{\multicolumn{2}{|c|}{ Total }} \\
\hline & \multicolumn{2}{|c|}{ Tidak setuju } & \multicolumn{2}{|c|}{ Ragu-ragu } & \multicolumn{2}{|c|}{ Setuju } & & \\
\hline & $\mathrm{Jml}$ & $\%$ & $\mathrm{Jml}$ & $\%$ & $\mathrm{Jml}$ & $\%$ & $\mathrm{Jml}$ & $\%$ \\
\hline $\begin{array}{l}\text { Kurang } \\
\text { baik }\end{array}$ & 12 & 63,16 & 6 & 31,58 & 1 & 5,26 & 19 & 63,33 \\
\hline $\begin{array}{l}\text { Cukup } \\
\text { baik }\end{array}$ & 1 & 9,09 & 7 & 63,64 & 3 & $\begin{array}{l}27,2 \\
7\end{array}$ & 11 & 36,67 \\
\hline Baik & 0 & 0 & 0 & 0 & 0 & 0 & 0 & 0 \\
\hline Total & 13 & 43,33 & 13 & 43,33 & 4 & $\begin{array}{c}13,3 \\
4\end{array}$ & 30 & $\begin{array}{c}100,0 \\
0\end{array}$ \\
\hline
\end{tabular}

Sumber : Diolah dari data primer, 2015 
Tabel 11. Persepsi Masyarakat Menurut Tingkat Pengetahuan Rencana Relokasi

\begin{tabular}{|c|c|c|c|c|c|c|c|c|}
\hline \multirow{3}{*}{$\begin{array}{l}\text { Tingkat } \\
\text { Pengetahuan }\end{array}$} & \multicolumn{6}{|c|}{ Persepsi Masyarakat } & \multirow{2}{*}{\multicolumn{2}{|c|}{ Total }} \\
\hline & \multicolumn{2}{|c|}{ Tidak setuju } & \multicolumn{2}{|c|}{ Ragu-ragu } & \multicolumn{2}{|c|}{ Setuju } & & \\
\hline & $\mathrm{Jml}$ & $\%$ & $\mathrm{Jml}$ & $\%$ & Jml & $\%$ & $\mathrm{Jml}$ & $\%$ \\
\hline Tidak mengetahui & 4 & 66,67 & 2 & 33,33 & 0 & 0 & 6 & 13,00 \\
\hline Cukup mengetahui & 9 & 42,86 & 10 & 47,62 & 2 & 9,52 & 21 & 80,00 \\
\hline Mengetahui & 0 & 0 & 1 & 33,33 & 2 & 66,67 & 3 & 7,00 \\
\hline Total & 13 & 43,33 & 13 & 43,33 & 4 & 13,34 & 30 & 100,00 \\
\hline
\end{tabular}

e. Pengetahuan Rencana Relokasi

Rencana relokasi sebagai obyek yang dijadikan sasaran persepsi, merupakan faktor yang amat mempengaruhi persepsi masyarakat. Oleh karena itu pengetahuan masyarakat tentang rencana relokasi sangatlah penting diupayakan, sehingga masyarakat bisa memberikan persepsi atas rencana pemerintah tersebut. Tingkat pengetahuan masyarakat tentang rencana relokasi diketahui bahwa sebagian besar responden menyatakan cukup mengetahui, dengan kata lain masyarakat sekedar mengetahui tapi tidak secara keseluruhan/tidak jelas.

Dengan demikian Persepsi masyarakat terhadap rencana relokasi menurut tingkat pengetahuan rencana relokasi, dapat dilihat pada Tabel 11.

Berdasarkan Tabel 11, diperoleh bahwa pada kategori pengetahuan masyarakat tidak mengetahui tentang rencana relokasi, ada dua persepsi yang timbul yaitu tidak setuju dan ragu-ragu, masing-masing sebesar 66,67 persen dan 33,33 persen. Pada kategori cukup mengetahui, persepsi yang menyatakan tidak setuju yaitu sebesar 42,86 persen, ragu-ragu sebesar 47,62 persen, dan setuju sebesar 9,52 persen. Pada kategori masyarakat yang mengetahui tentang rencana relokasi, persepsi masyarakat yang timbul yaitu ragu-ragu dan setuju, masing-masing sebesar 33,33 persen dan 66,67 persen.

Uraian tersebut dapat disimpulkan bahwa sebagian besar masyarakat yang tidak mengetahui rencana relokasi menyatakan persepsi tidak setuju, dan bagi masyarakat yang cukup mengetahui, sebagian besar menyatakan persepsi tidak setuju dan raguragu, sedangkan menurut masyarakat yang mengetahui, sebagian besar menyatakan persepsi setuju dengan rencana relokasi.

\section{Hubungan Persepsi Masyarakat dengan Faktor-Faktor yang Mempengaruhinya}

1. Analisis Uji Statistik Hubungan Persepsi Masyarakat dengan Faktor-Faktor yang Mempengaruhinya

Rencana pemerintah dalam rangka menanggulangi bencana banjir melalui kegiatan relokasi permukiman penduduk di pinggiran sungai, akan membentuk suatu persepsi bagi masyarakat yang menjadi objek dalam rencana ini. Dihubungkan dengan penjelasan tentang faktor-faktor yang mempengaruhi persepsi, maka penelitian tentang persepsi masyarakat terhadap rencana relokasi pada masyarakat Kelurahan Dendengan Dalam perlu mengetahui beberapa hal, sebagai berikut :

a. Konteks the perceiver masyarakat lingkungan I sebagai orang yang memberikan persepsi. Hal-hal yang perlu diperhatikan dari konteks ini menyangkut kondisi internal masyarakat yang dapat mempengaruhi persepsi yaitu karakteristik internal individu dalam hal ini diwakili kondisi ekonomi keluarga.

b. Konteks situasi meliputi kondisi fisik, sosial-budaya, dan organisasional. Kondisi fisik yang mempengaruhi persepsi masyarakat dalam rencana relokasi yaitu hal-hal yang berkaitan dengan kondisi fisik dan lingkungan tempat tinggal masyarakat. Kondisi sosial yang terjalin di dalam masyarakat juga menjadi faktor yang mempengaruhi persepsi masyarakat terhadap rencana relokasi. 
Selain itu, kondisi organisasional baik yang terdapat didalam masyarakat maupun pemerintah akan mempengaruhi keadaan masyarakat dalam menentukan persepsinya terhadap rencana relokasi.

c. Karakteristik dari objek yang dipersepsikan, yaitu rencana relokasi permukiman penduduk di sekitar sungai, seperti meliputi latar belakang rencana relokasi, fasilitas prasarana dan sarana, dan bagaimana prosedur yang terdapat dalam rencana tersebut. Informasi tentang deskripsi rencana relokasi ini akan sangat menentukan persepsi masyarakat terhadap rencana tersebut, sehingga upaya pemerintah untuk mensosialisasikan rencana relokasi penting dilakukan.

Setelah diketahui dan dibahas beberapa faktor yang mempengaruhi persepsi masyarakat terhadap rencana relokasi, maka selanjutnya dilakukan analisis uji statistik untuk mengetahui hubungan antara persepsi masyarakat dengan faktor yang mempengaruhinya. Analisis uji statistik yang digunakan tersebut yaitu melalui perhitungan chi-square. Hasil analisis Chi-Square hubungan kondisi ekonomi, kondisi fisik, kondisi sosial budaya, dan tingkatan pengetahuan rencana relokasi, dengan persepsi masyarakat dapat dilihat pada Tabel 12.

Hasil uji hubungan kondisi ekonomi, fisik/lingkungan, sosial-budaya, organisasi (upaya sosialisasi rencana relokasi), dan pengetahuan masyarakat akan rencana pemerintah untuk merelokasi pemukiman di Lingkungan I dengan persepsi masyarakat tentang rencana relokasi, dengan nilai $p<$ 0,05 menandakan hipotesis nol (Ho) ditolak.

Berdasarkan hasil analisis chi-squre yang terangkum pada Tabel 21, diperoleh bahwa pada variabel kondisi ekonomi, fisik dan sosial budaya menghasilkan nilai $p$ masingmasing sebesar $0,890,0,599$ dan 0,835 . Nilai $p$ yang diperoleh tersebut $>\alpha 0,05$, maka menandakan bahwa hipotesis nol $\left(\mathrm{H}_{0}\right)$ yang menyatakan tidak ada hubungan persepsi masyarakat tentang rencana relokasi dengan kondisi ekonomi, fisik dan sosial budaya diterima.

Bertolak belakang dengan uraian diatas, variabel kondisi organisasi (upaya sosialisasi) dan pangetahuan masyarakat tentang rencana relokasi menghasilkan nilai $p<0,05$ yaitu masing-masing 0,012 dan 0,044 . Nilai ini menandakan bahwa Hipotesis nol $\left(\mathrm{H}_{0}\right)$ yang menyatakan tidak ada hubungan antara persepsi masyarakat tentang rencana relokasi dengan upaya pemerintah mensosialisasi rencana relokasi dan pengetahuan masyarakat ditolak, atau dengan kata lain ada hubungan.

Tabel 12. Hasil Analisis Chi-Square Hubungan Kondisi Ekonomi, Kondisi Fisik, Kondisi Sosial Budaya, Kondisi Organisasi dan Pengetahuan Masyarakat dengan Persepsi Masyarakat

\begin{tabular}{clcc}
\hline No & \multicolumn{1}{c}{ Uji Hubungan } & \multicolumn{1}{c}{ Pvalue } & Kesimpulan \\
\hline 1 & $\begin{array}{l}\text { Kondisi ekonomi dengan persepsi } \\
\text { masyarakat tentang rencana relokasi }\end{array}$ & $1.130(0,890)$ & Tidak ada hubungan \\
2 & $\begin{array}{l}\text { Kondisi fisik dengan persepsi masyarakat } \\
\text { tentang rencana relokasi }\end{array}$ & $1,025(0,599)$ & Tidak ada hubungan \\
3 & $\begin{array}{l}\text { Kondisi sosbud dengan persepsi } \\
\text { masyarakat tentang rencana relokasi }\end{array}$ & $1,452(0,835)$ & Tidak ada hubungan \\
4. & $\begin{array}{l}\text { Kondisi organisasi dengan persepsi } \\
\text { masyarakat tentang rencana relokasi }\end{array}$ & $8,883(0,012)$ & Ada hubungan \\
5. $\begin{array}{l}\text { Pengetahuan masyarakat dengan persepsi } \\
\text { masyarakat tentang rencana relokasi }\end{array}$ & $9,780(0,044)$ & Ada hubungan
\end{tabular}

Sumber : Data primer yang diolah, 2015 
Hasil penelitian tersebut dapat disimpulkan bahwa ada hubungan antara upaya pemerintah dalam mensosialisasikan program dan besarnya pemahaman masyarakat akan rencana relokasi tersebut dengan persepsi masyarakat mengenai rencana pemerintah untuk merelokasi pemukiman di Lingkungan I. Kondisi ekonomi, fisik, dan sosial budaya yang ditimbulkan pasca bencana banjir, ternyata tidak mempunyai hubungan dengan persepsi masyarakat Lingkungan I.

2. Pembahasan Hubungan Persepsi Masyarakat dengan Faktor-Faktor yang Mempengaruhinya.

a. Hubungan Persepsi Masyarakat dengan Kondisi Ekonomi Keluarga.

Berdasarkan uji statistik Chi-Square dihasilkan kesimpulan kondisi ekonomi keluarga pasca bencana banjir tidak mempunyai hubungan dengan persepsi masyarakat tentang rencana relokasi. Hal ini beralasan, mengingat dari hasil perhitungan persepsi masyarakat menurut kondisi ekonomi yang terangkum pada Tabel 16 mendapati bahwa pada kondisi keluarga yang baik, maupun kurang baik (cukup), sebagian besar menyatakan tidak setuju dengan rencana relokasi. Demikian halnya pada masyarakat dengan perekonomian baik yang merasa ragu dengan program pemerintah.

Berdasarkan hasil wawancara dengan responden, diperoleh beberapa alasan yang menunjang kondisi diatas, antara lain : banyak responden yang menyatakan bencana banjir sama sekali tidak berpengaruh signifikan atau tidak merubah kondisi ekonomi menjadi lebih buruk, sehingga masyarakat merasa tidak perlu pindah tempat tinggal. Selain itu jauhnya lokasi relokasi menimbulkan kekhawatiran masyarakat atas pekerjaan atau usaha kerja yang tidak akan banyak membuat perekonomian keluarga menjadi lebih baik, atau minimal tetap. Persepsi masyarakat yang masih ragu atas rencana pemerintah, lebih didasari kurangnya penjelasan tentang hak dan status kepemilikan rumah / lahan.

Persepsi masyarakat yang setuju dengan rencana relokasi sebagian besar kondisi ekonominya tidak baik, namun ada juga masyarakat dengan kondisi ekonomi cukup yang setuju dengan program relokasi tersebut. Hal ini disebabkan status kepemilikan tempat tinggalnya yang bukan milik sendiri (milik keluarga).

b. Hubungan Persepsi Masyarakat dengan Kondisi Fisik / Lingkungan.

Persepsi masyarakat tentang rencana relokasi juga tidak berhubungan dengan kondisi fisik / lingkungan pasca bencana banjir. Hasil uji Chi-Square tersebut, didukung dari hasil perhitungan persepsi masyarakat menurut kondisi fisik pada Tabel 17 yang memperoleh data bahwa persepsi masyarakat yang tidak setuju dengan rencana relokasi justru didominasi masyarakat yang menilai kondisi fisik memburuk, bukan kondisi yang membaik.

Kondisi tersebut memperlihatkan bahwa ternyata pendapat masyarakat yang tidak setuju, sama sekali tidak dipengaruhi oleh adanya perubahan kondisi fisik lingkungan pasca banjir. Masyarakat menilai walaupun bencana banjir telah mengakibatkan kondisi fisik lingkungan berubah (memburuk), namun kondisi tersebut tidak mempengaruhi masyarakat untuk setuju dengan rencana relokasi. Persepsi masyarakat terhadap kondisi fisik pasca bencana banjir tersebut mengandung pengertian bahwa secara fungsinya tidak berubah dan masih bisa diperbaiki, sehingga responden merasa tidak perlu untuk pindah tempat tinggal.

Persepsi masyarakat yang ragu dan setuju dengan rencana relokasi disebabkan kondisi fisik rumah yang tidak bisa diperbaiki karena alasan ekonomi, selain itu kondisi fisik rumah yang tidak mampu lagi menampung anggota keluarga akibat banyaknya jumlah tanggungan keluarga, sehingga responden pada kelompok ini pasrah dengan keputusan pemerintah.

c. Hubungan Persepsi Masyarakat dengan Kondisi Sosial Budaya

Perhitungan analisis uji Chi-Square menghasilkan juga bahwa kondisi sosialbudaya ternyata tidak berhubungan dengan persepsi masyarakat tentang rencana relokasi. Hasil uji Chi-Square tersebut, didukung dari 
hasil perhitungan persepsi masyarakat menurut kondisi sosial budaya pada Tabel 18 yang memperoleh data bahwa persepsi masyarakat yang tidak setuju dengan rencana relokasi didominasi oleh masyarakat yang menilai kondisi sosial budaya pasca bencana banjir mengalami penurunan (memburuk). Sedangkan kondisi sosial budaya yang membaik, banyak masyarakat merasa ragu dengan rencana relokasi. Masyarakat berpendapat bahwa bencana banjir tidak mengubah hubungan sosial dan tali silahturahmi yang terjalin sebelum banjir, malahan lebih meningkatkan hubungan sosial dalam lingkungan tersebut.

Telah diuraikan sebelumnya bahwa pasca bencana banjir menyebabkan kesadaran masyarakat akan dampak banjir lebih meningkat sehingga aktivitas kemasyarakatan atau sosial juga bertambah. Berdasarkan penjelasan tersebut, dapat disimpulkan perubahan kondisi sosial budaya yang terjadi pasca banjir tidak berhubungan dengan persepsi masyarakat Lingkungan I.

d. Hubungan Persepsi Masyarakat dengan Kondisi Organisasi (Upaya Sosialisasi Pemerintah).

Perhitungan analisis uji Chi-Square menghasilkan bahwa terdapat hubungan antara kondisi organisasi / upaya sosialisasi pemerintah kepada masyarakat dengan persepsi masyarakat tentang rencana relokasi. Hasil uji Chi-Square tersebut, didukung dari hasil perhitungan persepsi masyarakat menurut kondisi organisasi pada Tabel 10 yang memperoleh data bahwa persepsi masyarakat yang tidak setuju dengan rencana relokasi didominasi oleh masyarakat yang menilai upaya sosialisasi pemerintah kurang baik.

Bencana banjir merupakan bencana yang perlu diantisipasi atau ditanggulangi oleh masyarakat maupun pemerintah selaku pihak yang berkuasa dan bertanggung jawab. Relokasi pemukiman yang diprogramkan oleh pemerintah guna menanggulangi atau mengantisipasi bencana banjir di wilayah pinggiran DAS hendaknya perlu disosialisasikan. Hal ini penting dilakukan agar masyarakat memahami sepenuhnya informasi tentang rencana pemerintah tersebut, dan juga sebagai kesempatan bagi masyarakat untuk menyampaikan aspirasi/keinginan masyarakat.

Upaya pemerintah untuk mensosialisaskan rencana relokasi Lingkungan I Kelurahan Dendengan Dalam dinilai belum dilakukan secara merata, bahkan sebagian berpendapat tidak pernah dilakukan, sehingga menimbulkan kesimpangsiuran informasi dan pemahaman tentang relokasi yang direncanakan pemerintah.

e. Hubungan Persepsi Masyarakat dengan Tingkat Pengetahuan Rencana Relokasi

Perhitungan analisis uji Chi-Square juga menghasilkan bahwa pengetahuan masyarakat tentang rencana relokasi mempunyai hubungan dengan persepsi masyarakat atas program pemerintan tersebut. Hasil pengujian Chi-Square tersebut, didukung juga dari hasil perhitungan persepsi masyarakat menurut tingkat pengetahuan rencana relokasi yang terangkum pada Tabel 11, memperoleh data bahwa sebagian besar masyarakat yang tidak dan cukup mengetahui tentang informasi apapun yang menyangkut relokasi ini, berpersepsi ragu bahkan tidak setuju dengan rencana relokasi.

Hal tersebut sangat memungkinkan mengingat pengetahuan masyarakat tentang rencana relokasi sangat ditentukan oleh banyaknya informasi yang diterima oleh masyarakat. Berdasarkan penjelasan upaya pemerintah dalam mensosialisasikan rencana relokasi, diketahui ternyata upaya sosialisasi pemerintah belum secara resmi dan merata menjangkau seluruh masyarakat Lingkungan I yang berada di pinggiran DAS Tondano. Kondisi ini menyebabkan masyarakat kurang bahkan tidak mengetahui pasti seluruh informasi tentang rencana relokasi ini.

Hasil penelitian memperoleh ada beberapa hal, selain kurangnya sosialisasi yang diupayakan pemerintah yang juga menyebabkan kondisi diatas, antara lain : 1) sosialisasi hanya diberikan kepada tokoh masyarakat dan tokoh agama; 2) sumber informasi yang diterima berasal dari kabar mouth to mouth; 3) masyarakat tidak pernah menghadiri kegiatan sosialisasi; dan 4) 
informasi yang diberikan pemerintah kurang/tidak lengkap. Masyarakat menilai kurang intensnya sosialisasi pemerintah tersebut, menyebabkan juga masyarakat merasa tidak dilibatkan dalam proses perencanaan dan pengambilan keputusan. Disisi lain, adanya informasi rencana relokasi yang berlokasi di dua daerah dan kemungkinan adanya alternatif lain, menambah keraguan masyarakat akan keseriusan pemerintah dalam menanggulangi atau mengantisipasi bencana banjir di Lingkungan I.

\section{KESIMPULAN DAN SARAN}

\section{Kesimpulan}

Berdasarkan hasil penelitian dan pembahasan yang telah diuraikan sebelumnya, maka diambil kesimpulan sebagai berikut:

1. Keadaan masyarakat di Lingkungan I Kelurahan Dendengan Dalam pasca bencana banjir tidak mempengaruhi perekonomian keluarga yaitu tetap pada kondisi ekonomi yang cukup baik, namun kondisi fisik mengalami perubahan menjadi buruk, dan kondisi sosial budaya yang mengalami perubahan yang justru lebih meningkat (membaik). Hasil penelitian juga menunjukkan bahwa kondisi organisasi (upaya sosialisasi pemerintah) berada pada kategori kurang baik, sehingga berakibat masyarakat kurang memahami / mengetahui rencana relokasi tersebut.

2. Masyarakat Lingkungan I Kelurahan Dendengan Dalam menyatakan persepsi ragu-ragu dan tidak setuju dengan rencana pemerintah untuk merelokasi pemukiman. Sikap masyarakat tersebut sebagian besar merupakan sikap yang diambil oleh masyarakat yang berada pada golongan kondisi ekonomi kurang baik, kondisi fisik yang memburuk dan tetap, kondisi sosial budaya yang memburuk dan membaik, dan kondisi organisasi yang kurang dan cukup baik, serta kurangnya (cukup) pengetahuan masyarakat dengan jelas secara keseluruhan rencana relokasi tersebut.
3. Faktor-faktor yang mempunyai hubungan dengan persepsi masyarakat Lingkungan I Kelurahan Dendengan Dalam antara lain kondisi organisasi (upaya sosialisasi pemerintah) dan tingkat pengetahuan masyarakat tentang informasi keseluruhan rencana relokasi, sedangkan yang tidak antara lain kondisi ekonomi, fisik, dan sosial budaya.

\section{Saran}

1. Intensitas kegiatan sosialisasi pemerintah perlu ditingkatkan baik secara kuantitas maupun kualitas.

2. Perlu dibentuk tim yang melibatkan anggota masyarakat dari semua kalangan dan diberi arahan atau bekal pengetahuan relokasi.

3. Perlu dibuat bentuk variasi sosialisasi selain pertemuan, seperti menggunakan media cetak, dan elektronik.

\section{DAFTAR PUSTAKA}

Adiputro, B.A., 2002. Arahan Mitigasi Bencana Perkotaan di Indonesia. Jakarta BAKORNAS PBP.

Adisasmita, R., 2010. Pembangunan Kawasan dan Tata Ruang. Jakarta: Graha Ilmu.

Arikunto, Suharsini. 2004. Prosedur Penelitian: Suatu Pendekatan Praktek. Rineka Cipta. Bandung.

BAKORNAS PB., 2005. Perencanaan dan Koordinasi dalam Lokakarya Manajemen Kedaruratan dan Perencanaan Kontinjensi.

, 2007. Pedoman

Penangguangan Bencana, Jakarta: Pelaksana Harian Bakornas PB.

Bungin. B., 2003. Analisis Data Penelitian Kualitatif. Jakarta : PT. Raja Grafindo Persada. Kualitatif : Komunikasi, Ekonomi, Kebijakan. 
Dessler, G., 2005. Manajemen Sumber Daya Manusia. Ed 9. Jakarta: PT. Indeks.

Dikmen, N., 2006. Relocation or Rebuilding in the Same Area: An Important Factor for Decision Making for Post-Disaster Housing Projects. Unpublished Report. Montreal: University of Montreal

Harliani, 2014. Persepsi Masyarakat Kampung Citeunteung Kabupaten Bandung Tentang Bencana Relokasi Akibat Bencana Banjir. Jurnal. ITB. Bandung.

Herujito. MY., 2001. Dasar-Dasar Manajemen, Jakarta: Grasindo.

Ibnu, H., 1999. Dasar-dasar Penelitian Kuantitatif. Jakarta: PT.Raja Grafindo Persada.

IDEP., 2004. Panduan Umum Penanggulangan Bencana Untuk Masyarakat (PUPBM). Bali : Yayasan IDEP

Johara,T., 1999. Tata Guna Tanah Dalam Perencanaan Pedesaan, Perkotaan, dan Wilayah .Bandung: Edisi 3. ITB Bandung.

Kuncoro Mudrajad, 1997. Ekonomi Pembangunan, Teori, masalah dan kebijakan, Cetakan pertama, Unit penerbitan dan percetakan akademi manajemen perusahaan YKPN, Yogyakarta
Kuswartojo, T., 2005. Perumahan dan Permukiman Di Indonesia. Bandung: ITB

Kementerian Kesehatan RI. , 2011. Profil Kesehatan Indonesia 2010. http://www.depkes.go.id

Malayu, SP., 2005. Manajemen Sumber Daya Manusia. Jakarta: Bumi Aksara.

Mindriyani, N., 2012. Penanganan Bencana Lamban Akibat Koordinasi Kurang. Kampar Riau.

Moleong. L.J., 2010. Metodologi Penelitian Kualitatif. Bandung : PT. Remaja.

Nawawi H., 2003. Metode Penelitian Bidang Sosial. UGM Press. Jogyakarta.

Nuryana, M., 2011. Pelembagaan Pendayagunaan Sumber Daya Manusia Kesejahteraan Sosial yang Terintegratif dalam Penanggulangan Bencana Alam. Diambil dari www.depsos.go.id. Pada tanggal 27 Maret 2012. Jakarta: KEMENKES RI.

Prabu, A. 2005. Manajemen Sumber Daya Manusia Perusahaan. Bandung; Remaja Rosdakarya.

www.http.news liputan6.com, diunggah pada bulan April 2015. 